\title{
Comprehensive view on the ductility of basalt fiber reinforced concrete focus on lightweight expanded clay
}

\author{
Vera V. Galishnikova ${ }^{1}$, Paschal C. Chiadighikaobi ${ }^{*}$, Dafe A. Emiri ${ }^{2}$ \\ ${ }^{1}$ Peoples' Friendship University of Russia (RUDN University), 6 Miklukho-Maklaya St., Moscow, 117198, Russian Federation \\ ${ }^{2}$ Cross River University of Technology, PMB 1123, Calabar, Federal Republic of Nigeria \\ *passydking2@mail.ru
}

\section{Article history:}

Received: May 14, 2019

Revised: October 10, 2019

Accepted: October 13, 2019

\section{For citation}

Galishnikova V.V., Chiadighikaobi P.C., Emiri D.A. (2019). Comprehensive view on the ductility of basalt fiber reinforced concrete focus on lightweight expanded clay. Structural Mechanics of Engineering Constructions and Buildings, 15(5), 360-366. http://dx.doi.org/10.22363/1815-5235-2019$15-5-360-366$
Abstract

Relevance. Ductility of basalt fiber reinforced concrete is an interesting property of basalt fiber reinforced concrete. However, very few experiments on this property is documented. The aim of the work. This paper provides a summarized analysis and review of existing publications on the ductility of lightweight basalt fiber reinforced concrete. Methods. This paper provides a comprehensive study on ductility of basalt reinforced concrete and lays the framework for proper laboratory experiment on the ductility of basalt fiber reinforced concrete. Results. From the findings of this review paper, ductility of dispersed basalt fiber reinforced concrete depends not only in the percentage of basalt fiber in the concrete but in the length and diameter of the basalt fiber. Increase in the percentage of basalt fiber in the concrete yielded an increase in the concrete ductility.

Keywords: reinforcement; ductility of lightweight basalt fiber concrete; expanded clay

\section{Introduction}

\section{General overview}

Basalt fibers are made from basalt rocks which are the most common rock type in the earth's crust. The basalt fibers are manufactured from melted rock which are then extruded through small nozzles to produce continuous basalt fiber. Basalt fiber are produced in various forms which are used for concrete reinforcement. The varieties mostly used as concrete reinforcement are: basalt rebar, basalt grids (mesh), chopped basalt fiber [1-3]. Comparing the physico-chemical properties of basalt rocks [4], basalt fibers which are derived from natural rocks are superior to traditional

Vera V. Galishnikova, Professor, Director of the Department of Civil Engineering, Academy of Engineering.

Paschal Chimeremeze Chiadighikaobi, postgraduate $\mathrm{PhD}$ student of the Department of Civil Engineering, Academy of Engineering.

Dafe Aniekan Emiri, Lecturer in the Department of Civil Engineering.

(C) Galishnikova V.V., Chiadighikaobi P.C., Emiri D.A., 2019 This work is licensed under a Creative Commons Attribution 4.0 International License https://creativecommons.org/licenses/by/4.0/ thermal insulation/heat-resistant substances, such as ordinary fiberglass and asbestos. Similarly, basalt fiber has better operational properties, in terms of environmental friendliness of production [5].

Ductility can be defined as the measure of a material's ability to plastically deform without fracturing when placed under a tensile stress that exceeds its yield strength. Ductility highly depends on a material's chemical composition, a material's crystalline structure, and the temperature at which the ductility is being measured.

The term ductility in seismic design can be understood as the ability of a structure to undergo large amplitude cyclic deformations in elastic range without substantial reduction in strength. Ductile structures are noteworthy of being able to dissipate significant amount of energy during those cyclic deformations. Therefore, to understand the effectiveness of basalt fibres under cyclic loading in beam-column joint, determination of ductility is crucial [6].

Ductility can also be express in formula using the load-deflection or moment-curvature diagrams. 
For reinforced concrete sections, ductility can be expressed in the form of curvature ductility $\mu_{\phi}[3]$ :

$$
7 \mu_{\phi}=\frac{\phi_{u}}{\phi_{y}},
$$

where $\phi_{u}$ - the curvature at ultimate when the concrete strain reaches a specified limiting value; $\phi_{y}-$ the curvature when the tension reinforcement first reaches the yield strength.

These are illustrated in figure 1. Curvature can generally be determined by the expression

$$
\phi=\frac{\varepsilon_{1}+\varepsilon_{2}}{h},
$$

where $\varepsilon_{1}$ and $\varepsilon_{2}$ are the strains at top and bottom of a section of height $h$.

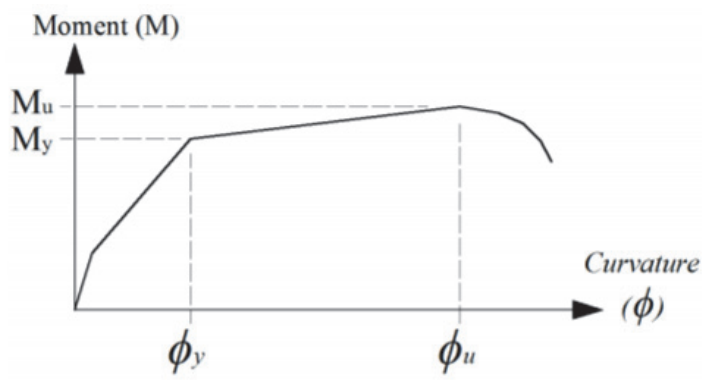

Figure 1. Definition of ductility [7]

Concrete structures are usually reinforced because plain concrete has strong limitations to resist tension. One of the foremost reinforcing materials is steel; it suits well as reinforcement but has well known pros and cons. Fiber reinforced polymers (FRP) have over the past years became an interesting alternative as a reinforcement for concrete [8]. Concrete is one of the most widely used construction material. Concrete has several advantages some of which are durability, formability and desired mechanical strength which gives concrete an edge over the other conventional building material but it has few disadvantages such as low tensile strength and strain capacity [9-12].

\section{Literature review}

Ablesimov N.E. and Malova Yu.G., 2016. In the article [13], the authors summarized research data on the basalt rock fibres and wool, and composites reinforced. In their research, the authors covered some areas where refined basalt rock materials are used. These areas mentioned are in the field of chemical, automotive and economic sciences.

Roy B. and Laskar A.I., 2017. In the authors' experimental investigation, the yield displacement was determined based on the theory of reduced stiffness equivalent elasto-plastic yield [14]. The reduced stif- fness was calculated as secant stiffness at $75 \%$ of design load [15]. The post-peak displacement when the loadcarrying capacity underwent $20 \%$ reduction was considered as the ultimate displacement [14]. Figure 2 shows the ductility of all the test basalt fibers. Ductility of basalt fiber reinforced concrete (BFRC) specimens having 1 and $2 \%$ fibers were found to be decreased by 19 and $38 \%$ than the corresponding steel fiber reinforced concrete (SFRC) specimens. It is noteworthy that the ultimate displacement of both types of specimens at respective fiber percentages was found to be same, but specimens containing basalt fibers had higher yield displacement compared to specimens containing steel fibers (SF1 \& SF2). This in turn reduced the ductility of BFRC specimens.

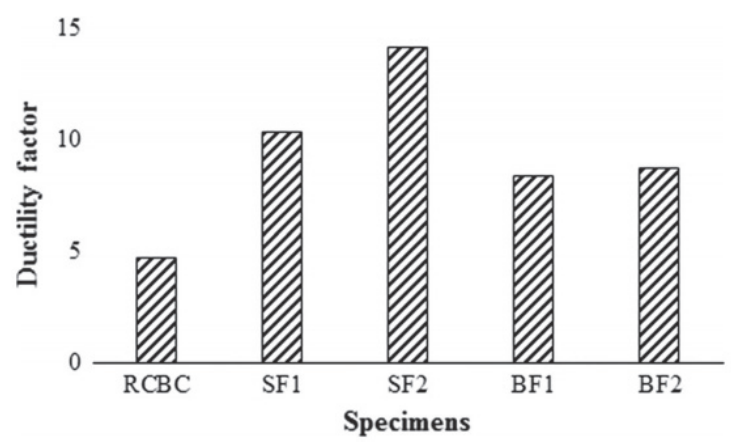

Figure 2. Ductility factor of test specimen

A.E.A. Elshekh et al., 2014. In the research paper evaluation, the effectiveness of chopped basalt fiber on the properties of high strength concrete [16], the authors stated that high amount of steel reinforcement content, durability and ductility issues have led the development of alternative types for reinforcement of high strength concrete (HSC) [17]. Fiber reinforcement (FR) of concrete has been investigated as strengthening materials with different techniques such as external and bar reinforcement. This is due to high contributions of the FR on the mechanical properties of HSC such as high compressive strength, toughness and ductility. Their main objective is to investigate the effect of chopped basalt fiber stands (CBFS) on the fresh and harden properties of HSC as a new internal strengthening material. The experimental results showed that the workability of HSC was affected negatively with increase of CBFS content. It is also shown that the early and long terms of compressive strength was not supported using the CBFS. Whereas, split and flexural tensile strengths were significantly improve. From the analysis it was also observed that the brittleness was significantly decreased and its toughness and ductility were steadily improved. Therefore, it can be concluded that the CBFS is a suitable strengthening material to pro- 
duce ductile HSC. The toughness and ductility of the chopped basalt fiber stands (CBFS) concrete cubes were observed through the test in stress-strain relationship curves for all specimens. Furthermore, due to improvement of tensile and flexural strength, the toughness and ductility of HSC was enhanced.

Ludovico et al., 2010. In the authors' paper [18] Structural upgrade using basalt fibers for concrete confinement, the authors used basalt fiber laminates for confinement of concrete cylinders. The result of their experiment showed a better performance of basalt fiber over glass fiber-reinforced polymer in terms of compressive strength and ductility.

High et al., 2015; Kizilkanat et al., 2015; Lipator et al., 2015; Hannawi et al., 2016. The authors [19] in their research studied the use of basalt fibers as additive in concrete and they went further to observe that there was a significant increase in flexural strength and slight improvement in compressive strength. Similar studies were also carried out by [20-22], where it was found that the addition of basalt fiber in concrete improved ductility, elastic modulus, flexural strength, splitting tensile strength and fracture energy.

Lightweight concrete is assumed not to be considered as a special material lately because it is now been included in many codes of practice, such as the American Concrete Institute (ACI) [23]. In contrast with regular concrete lightweight concrete has lower density and increased deformability. The material properties and mechanics of lightweight concrete have long been identified and still continue to attract interest as shown in [24-26]. Many structural and bridge applications have been reported by authors such as authors of $[27 ; 28]$. High strength has also been achieved by $[29 ; 30]$.

Abdelhamid et al., 2014. In the authors' paper [31], they presented analytical and experimental results on ductility of reinforced lightweight concrete beams and columns in the form of moment curvature relationships, and compared the response with that of normal reinforced concrete members. From the experimental part of their research, it is limited to flexural tests on beams made of lightweight concrete. The latter is obtained with natural lightweight aggregates. Further in the research, lightweight concrete beams and columns showed a more ductile behavior than normal concrete members and the analytical model reproduced the response with very good accuracy. The analysis shows the lightweight ductility was more pronounced in columns subjected to axial compression forces and bending.

Buchkin A.V., 2011. The author in the project work [32] explained that the construction of modern buildings and structures requires the use of concrete with high performance properties, such as compressive and tensile strength, crack resistance, impact strength, wear resistance, corrosion resistance, frost resistance, etc. To achieve these, the transition to new types of concrete was facilitated by advances in the plasticization of concrete and mortar mixtures, and the emergence of new, more active mineral additives. Modifiers of concrete of the MB type, developed and manufactured on an industrial scale, made it possible to obtain fine-grained concrete of strength classes up to B90 with low permeability and corrosion resistance. At the same time, such concretes have insufficient tensile strength during bending, as well as high temperature and shrinkage deformations due to the increased consumption of cement. The challenge of improving the operational characteristics of finegrained concrete is solved by reinforcing it with various types of metallic and non-metallic fibers of mineral or organic origin.

\section{Problem statement}

This paper is a comparative review of earlier publications on the ductility of basalt fiber reinforced concrete, it analyzes and compares the ductility of lightweight BFRC and gravel BFRC.

\section{Method and analysis}

This research paper is based on the review of research and experimental papers of other authors from which analysis will be drawn.

\section{Ductility of lightweight basalt fiber reinforced concrete (BFRC)}

High strength of lightweight aggregate concrete leads to increased brittleness, therefore fiber reinforcement should be considered for improving strength and ductility.

Analyzing from the reviews detailed in this paper, lightweight aggregate concrete and the usual gravel coarse aggregate has the capability to increase it ductility when reinforced with basalt fiber. The volume of the fiber in the concrete mix affects the ductility growth. From $0.5 \%$ fiber increment in the concrete, a significant increase in the ductility of the concrete is seen. Adding lightweight aggregates to the concrete mix decreases the ductility of the concrete and at the same time increases the brittleness of the material. The shear and flexural definition of ductility index $\mu$ consist of the ratio of the area of the loaddeflection response. Shear ductility should only be measured on shear deformation [33].

Fiber volume fraction of $1.5 \%$ or higher achieves strain hardening faster than lower fiber volume fractions. By the addition of 10-20\% fly ash and silica- 
fume cement substitutes, the ductility and flexural strength of lightweight fiber-reinforced concrete are improved. This yields an increment of $50-150 \%$ flexural displacement (ductility) at ultimate load [24]. For lightweight aggregate fiber-reinforced concrete, ductility results from enforced crack resistance due to the fiber bridging concrete layers [34]. It can be concluded that adding fibers into the lightweight concrete mixtures increases the compressive strength of the concrete by $20 \%$, tensile strength by $80 \%$ and flexural strength by $90 \%$ [35]. In multi-story buildings, the dead load is decreased by using structural lightweight concrete $[19 ; 36 ; 37]$.

\section{Conclusion}

Review of the literatures reveal that till date, significant research has been conducted regarding the strength of lightweight concrete incorporating basalt fibers. Most of these studies are limited to the application of basalt fibers in enhancing mechanical properties of concrete under monotonic loading. However, little attempt has been made so far to investigate the effect of chopped basalt fiber on reinforced cement concrete (RCC). The enlisted authors above have been able to conduct some experiments on ductility of basalt fiber reinforced concrete and lightweight concrete. An attempt that therefore shows the behavior, ductility and energy dissipation capacity of basalt fiber reinforced concrete.

The brittle nature of lightweight aggregate concrete leads to sudden and precipitated failure. Therefore, adding fiber reinforcement improves ductility of lightweight concrete or normal-weight high-strength concrete. The addition of fibers to lightweight aggregate concrete increases the peak and residual frictional stresses. Fiber reinforcement may prevent congestion when additional reinforcement is required to provide ductility.

Lightweight concrete beams and columns were seen to show more ductile behavior than normal concrete members and the analytical model reproduced the response with very good accuracy. Lightweight ductility was more pronounced in columns subjected to axial compression forces and bending.

From the review, it can be stated that concrete containing basalt fibers could depict less ductile behavior compared to concrete with other types of fibers for all volume fraction of fibers. Basalt fiber reinforced concrete has higher energy absorption capacity and the increased ductility. Basalt fibers easily disperse within the concrete mix without causing segregation and that the fibers lose their shape due to the flexible structure.
Lightweight concrete offers undeniable isolation advantages but the reduction in the overall cost generated by the lower dead loads is often overwhelmed by the higher production cost, especially with factory produced expanded clay lightweight aggregates. Lightweight concrete becomes however more challenging when using natural volcanic rocks reserves to produce lightweight aggregates. On the other hand, even if the reduced stiffness of lightweight concrete requires a tighter deflection control, its higher ultimate strain confers a major advantage to lightweight concrete in the form of improved ductility and better energy absorption capacity.

\section{References}

1. Basalt fiber for smarter building systems. https://basalt-fiber.com/\#

2. Basaltic rocks and technologies for their use. http://www.naftaros.ru/kompozitsionnye_/bazaltovye_teh no/index.html

3. Dzhigiris D.D., Makhova M.F. (2002). Osnovy proizvodstva bazal'tovyh volokon i izdelij: monorafiya [Basics of the production of basalt fibers and products: monograph]. Moscow: Teploenergetik Publ. (In Russ.)

4. Kharun M., Koroteev D.D., Dkhar P., Zdero S., Elroba S.M. (2018). Physical and mechanical properties of basalt-fibered high-strength concrete. Structural Mechanics of Engineering Constructions and Buildings, 14(5), 396-403. http://dx.doi.org/10.22363/1815-5235-2018-14-5-396-403 (In Russ.)

5. Malova Yu.G. (2010). Fiziko-himicheskie svojstva steklobazal'tovyh alyumosilikatnyh volokon [Physico-chemical properties of glass basalt aluminosilicate fibers] (Diss. Cand. Chem. Sciences). Khabarovsk. (In Russ.)

6. Roy B., Laskar A.I. (2017). Cyclic behaviour of insitu exterior beam-column subassemblies with cold joint in column. Engineering Structure, (132), 822-833.

7. Olivia M., Mandal P. (2005). Curvature Ductility of Reinforced Concrete Beam. Journal of Civil Engineering, 6(1), 1-13.

8. Satya M.S., Indrajit N.P., Jagruti S. (2015). Study of ductility properties by effective replacement of steel with basalt fibre reinforced polymer. International Journal of Engineering Research and General Science, 3(3), 683-688.

9. Ahmet B.K., Nihat K., Veysel A., Swaptik C., Abdullah H.A. (2015). Mechanical properties and fracture behavior of basalt and glass fiber reinforced concrete: an experimental study. Construction and Building Materials, 100, 218-224. https://doi.org/10.1016/j.conbuildmat.2015.10.006

10. Tassew S.T., Lubell A.S. (2014). Mechanical properties of glass fiber reinforced ceramic concrete construct. Building Materials, 51, 215-224. 
11. Faiz U.A.S. (2013). Review of mechanical properties of short fibre reinforced geopolymer composites. Construction and Building Materials, (43), 37-49.

12. Jiang C., Fan K., Wu F., Chen D. (2014). Experimental study on the mechanical properties and microstructure of chopped basalt fibre reinforced concrete. Material Destruction, 58, 187-193.

13. Ablesimov N.E., Malova Yu.G. (2016). Stone (basalt) fiber: Research and scientific schools. Scientific Review. Technical science, (6), 5-9. (In Russ.)

14. Monjusha S., Biswajit R., Ruhul A.M., Aminul I.L. (2018). Effect of Chopped Basalt Fibers on the Cyclic Behavior of RCC Beam-Column Subassemblies. Arabian Journal for Science and Engineering, 43(4), 1865-1874. https://doi.org/10.1007/s13369-017-2801-y

15. Park R. (1989). Evaluation of ductility of structures and structural subassemblages from laboratory testing. Bulletin of the New Zealand National Society for Earthquake Engineering, 22(3), 155-166.

16. Elshekh A.E.A., Shafiq N., Nuruddin M.F., Fathi A. (2014). Evaluation the Effectiveness of Chopped Basalt Fiber on the Properties of High Strength Concrete. Journal of Applied Sciences, 14, 1073-1077.

17. Kharun M., Koroteev D. (2018). Effect of basalt fibers on the parameters of fracture mechanics of $\mathrm{MB}$ modifier based highstrength concrete. MATEC Web of Conferences, 251, 02003. https://doi.org/10.1051/matecconf/ 201825102003

18. Ludovico M.D., Prota A., Manfreidi G. (2010). Structural upgrade using basalt fibers for concrete confinement. Journal of Composites for Construction, 14(5), 541-552.

19. High C., Satsem H.M., Safty A.E., Rizkalla S.H. (2015). Use of basalt fibers for concrete structures. Construction and Building Materials, 96, 37-46.

20. Kizilkanat A.B., Kabay N., Akyuncu V., Choudhury S., Akea A.H. (2015). Mechanical properties and fracture behaviour of basalt and glass FRC: experimental study. Construction and Building Materials, 100, 218-224.

21. Lipatov Y.V., Gutrikov S.I., Manylov M.S., Zhukovskaya E.S., Lazoryak B.I. (2015). High alkali resistant basalt fibers for reinforcing concrete. Materials and Design, 73, 60-66.

22. Hannawi K., Bian H., Agbodjan W.P., Raghavan B. (2016). Effect of different types of fibers on the microstructure and the mechanical behaviour of UHPC. Composite Part B, 86, 214-220.

23. ACI 213R-87. (1987). Guide for Structural Lightweight Aggregate Concrete. American Concrete Institute, Detroit, Michigan.

24. Hong Zhi C. (2007). Mechanical properties of lightweight aggregate concrete - effect of lightweight aggregates on concrete ( $\mathrm{PhD}$ thesis). Hong Kong University.
25. Koh C.G., Teng M.Q., Wee T.H. (2008). A plasticdamage model for lightweight concrete and normal weight concrete. International Journal of Concrete Structures and Materials, 2(2), 123-136.

26. Muyasser M.J., Daham H.A., Saad M.R. (2011). Flexural behavior of lightweight concrete beams. European Journal of Scientific Research, 58(4), 582-592.

27. Russell H. (2007). Current Provisions and Needed Research for Lightweight Concrete in Highway Bridges. Publication No. FHWA-HRT-07-051. US Department of Transportation.

28. Waldron C.J., Cousins T.E., Nassar A.J., Gomez J.P. (2005). Demonstration of use of high-performance lightweight concrete in bridge superstructure in Virginia. Journal of performance of Constructed Facilities, 19(2), 146-154.

29. Katkhuda H., Hanayneh B., Shatarat N. (2009). Influence of silica fume on high strength of lightweight concrete. World Academy of Science, Engineering and Technology, 58, 781-788.

30. Yasar E., Atis C.D., Kilic A. (2004). High strength lightweight concrete made with ternary mixtures of cement, fly ash, silica fume, and scoria as aggregates. Turkish Journal of Engineering, Environment and Science, 28, 95-100.

31. Abdelhamid C., Jamal M.S., Saleh D. (2014). Ductility of reinforced lightweight concrete beams and columns. Latin American Journal of Solids and Structures, 11(7), 1251-1274.

32. Buchkin A.V. (2011). Melkozernistyj beton vysokoj korrozionnoj stojkosti, armirovannyj tonkim bazal'tovym voloknom [Fine-grained concrete of high corrosion resistance reinforced with thin basalt fiber] (Diss. of Candidate of Technical Sciences). Moscow. (In Russ.)

33. Ahmad S.H., Xie Y., Yu T. (1995). Shear ductility of reinforced lightweight concrete beams of normal strength and high strength concrete. Cement and Concrete Composites, 17(2), 147-159.

34. Arisoy B., Wu H.C. (2008). Material characteristics of lightweight, high-performance concrete reinforced with PVA. Construction and Building Materials, 22(4), 635-645.

35. Wang H.T., Wang L.C. (2013). Experimental study on static and dynamic mechanical properties of steel fiber reinforced lightweight aggregate concrete. Construction and Building Materials, 38(2), 1146-1151.

36. Balaguru P., Foden A. (1996). Properties of fiber reinforced structural lightweight concrete. American Concrete Institute Structural Journal, 93, 1-12.

37. ACI Committee 544. (2005). State-of-the-art report on fiber reinforced concrete. ACI 544.1R-96 (Reapproved 2002): Manual of Concrete Practice. Michigan: American Concrete Institute. 


\title{
Исследование влияния дисперсного армирования базальтовой фиброй на пластические свойства легких бетонов на керамзитовом гравии
}

\author{
В.В. Галишникова ${ }^{1}$, П.Ч. Чиадигхикаоби ${ }^{*}$, Д.А. Эмири ${ }^{2}$ \\ ${ }^{1}$ Российский университет дружбы народов, Российская Федерация, 117198, Москва, ул. Миклухо-Маклая, 6 \\ ${ }^{2}$ Технологический университет Кросс-Ривер, n/я 1123, Калабар, Федеративная Республика Нигерия \\ *passydking2@mail.ru
}

\section{История статьи:}

Поступила в редакцию: 14 мая 2019 г.

Доработана: 10 октября 2019 г.

Принята к публикации: 13 октября 2019 г.

Для циитирования

Galishnikova V.V., Chiadighikaobi P.C., Emiri D.A. Comprehensive view on the ductility of basalt fiber reinforced concrete focus on lightweight expanded clay (Исследование влияния дисперсного армирования базальтовой фиброй на пластические свойства легких бетонов на керамзитовом гравии) // Строительная механика инженерных конструкций и сооружений. 2019. Т. 15. № 5. C. 360-366. http://dx.doi.org/ $10.22363 / 1815-5235-2019-15-5-360-366$

\section{Аннотация}

Актуальность. Пластичность базальтофибробетона является одним из основных свойств этого материала. Авторами обнаружено, что пластичность базальтофибробетона всесторонне не изучена. Проведенные ранее исследования недостаточны. Цели. В данной работе представлен обобщенный анализ и обзор существующих исследований пластичности легкого базальтофибробетона. Методы. Проведено комплексное исследование пластичности базальтофибробетона и заложена основа для лабораторного эксперимента по пластичности базальтофибробетона. Результаты. Исходя из результатов проведенного обзора, можно сделать вывод о том, что пластичность дисперсно армированного базальтофибробетона зависит как от процента содержания, так и от диаметра и длины базальтовой фибры. Увеличение процента дисперсно армированного базальтофибробетона увеличивает пластичность бетона.

Ключевые слова: армирование; пластичность легкого базальтофибробетона; керамзит

\section{Список литературы}

1. Basalt fiber for smarter building systems. URL: https:// basalt-fiber.com/\#

2. Базальтовые породы и технологии их использования. URL: http:/www.naftaros.ru/kompozitsionnye_/ bazaltovye_tehno/index.html

3. Джчигирис Д.Д., Махова М.Ф. Основы производства базальтовых волокон и изделий. М.: Теплоэнергетик, 2002. $416 \mathrm{c.}$

4. Харун М., Коротеев Д.Д., Дхар П., Здеро С., Эльроба С.М. Физические и механические свойства базальтоволоконного высокопрочного бетона // Строительная механика инженерных конструкций и сооружений. Т. 14. № 5. C. 396-403. URL: http://dx.doi.org/10.22363/18155235-2018-14-5-396-403

5. Малова Ю.Г. Физико-химические свойства стеклобазальтовых алюмосиликатных волокон: дис. ... канд. хим. наук. Хабаровск, 2010. 143 с.

6. Roy B., Laskar A.I. Cyclic behaviour of in-situ exterior beam-column subassemblies with cold joint in column // Engineering Structure. 2017. Vol. 132. Pp. 822-833.

Галишникова Вера Владимировна, доктор технических наук, професcop, директор департамента строительства Инженерной академии. Чиадигхикаоби Паскал Чимеремезе, аспирант департамента строительства Инженерной академии.

Эмири Дафе Аниэкан, преподаватель департамента строительства.
7. Olivia M., Mandal P. Curvature Ductility of Reinforced Concrete Beam // Journal of Civil Engineering. 2005. Vol. 6. No. 1. Pp. 1-13.

8. Satya M.S., Indrajit N.P., Jagruti S. Study of Ductility properties by effective replacement of Steel with Basalt Fibre Reinforced Polymer // International Journal of Engineering Research and General Science. 2015. Vol. 3. No. 3. Pp. 683-688.

9. Ahmet B.K., Nihat K., Veysel A., Swaptik C., Abdullah H.A. Mechanical properties and fracture behavior of basalt and glass fiber reinforced concrete: an experimental study // Construction and Building Materials. 2015. Vol. 100. Pp. 218-224. URL: https://doi.org/10.1016/ j.conbuildmat.2015.10.006

10. Tassew S.T., Lubell A.S. Mechanical properties of glass fiber reinforced ceramic concrete Construct // Building Materials. 2014. Vol. 51. Pp. 215-224.

11. Faiz U.A.S. Review of mechanical properties of short fibre reinforced geopolymer composites // Construction and Building Materials. 2013. Vol. 43. Pp. 37-49.

12. Jiang C., Fan K., Wu F., Chen D. Experimental study on the mechanical properties and microstructure of chopped basalt fibre reinforced concrete // Material Destruction. 2014. Vol. 58. Pp. 187-193.

13. Албесимов Н.Е., Малова Ю.Г. Каменное (базальтовое) волокно: научно-исследовательские и научные школы // Научное обозрение. Технические науки. 2016. № 6. C. 5-9. 
14. Monjusha S., Biswajit R., Ruhul A.M., Aminul I.L. Effect of Chopped Basalt Fibers on the Cyclic Behavior of RCC Beam-Column Subassemblies // Arabian Journal for Science and Engineering. 2018. Vol. 43. No. 4. Pp. 1865-1874. URL: https://doi.org/10.1007/s13369017-2801-y

15. Park $R$. Evaluation of ductility of structures and structural subassemblages from laboratory testing // Bulletin of the New Zealand National Society for Earthquake Engineering. 1989. Vol. 22. No. 3. Pp. 155-166.

16. Elshekh A.E.A., Shafiq N., Nuruddin M.F., Fathi A. Evaluation the Effectiveness of Chopped Basalt Fiber on the Properties of High Strength Concrete // Journal of Applied Sciences. 2014. Vol. 14. Pp. 1073-1077.

17. Kharun M., Koroteev D. Effect of basalt fibers on the parameters of fracture mechanics of $\mathrm{MB}$ modifier based highstrength concrete // MATEC Web of Conferences. 2018. Vol. 251. Article No. 02003. URL: https:// doi.org/10.1051/matecconf/201825102003

18. Ludovico M.D., Prota A., Manfreidi G. Structural upgrade using basalt fibers for concrete confinement // Journal of Composites for Construction. 2010. Vol. 14. No. 5. Pp. 541-552.

19. High C., Satsem H.M., Safty A.E., Rizkalla S.H. Use of basalt fibers for concrete structures // Construction and Building Materials. 2015. Vol. 96. Pp. 37-46.

20. Kizilkanat A.B., Kabay N., Akyuncu V., Choudhury S., Akea A.H. Mechanical properties and fracture behaviour of basalt and glass FRC: experimental study // Construction and Building Materials. 2015. Vol. 100. Pp. 218-224.

21. Lipatov Y.V., Gutrikov S.I., Manylov M.S., Zhukovskaya E.S., Lazoryak B.I. High alkali resistant basalt fibers for reinforcing concrete // Materials and Design. 2015. Vol. 73. Pp. 60-66.

22. Hannawi K., Bian H., Agbodjan W.P., Raghavan B. Effect of different types of fibers on the microstructure and the mechanical behaviour of UHPC // Composite Part B. 2016. Vol. 86. Pp. 214-220.

23. ACI 213R-87. Guide for Structural Lightweight Aggregate Concrete / American Concrete Institute. Detroit, Michigan, 1987.

24. Hong Zhi C. Mechanical properties of lightweight aggregate concrete - effect of lightweight aggregates on concrete: $\mathrm{PhD}$ thesis / Hong Kong University. 2007. 270 p.

25. Koh C.G., Teng M.Q., Wee T.H. A plastic-damage model for lightweight concrete and normal weight concrete // International Journal of Concrete Structures and Materials. 2008. Vol. 2. No. 2. Pp. 123-136.
26. Muyasser M.J., Daham H.A., Saad M.R. Flexural behavior of lightweight concrete beams // European Journal of Scientific Research. 2011. Vol. 58. No. 4. Pp. 582-592.

27. Russell H. Current Provisions and Needed Research for Lightweight Concrete in Highway Bridges // Publication No. FHWA-HRT-07-051 / US Department of Transportation. 2007.

28. Waldron C.J., Cousins T.E., Nassar A.J., Gomez J.P. Demonstration of use of high-performance lightweight concrete in bridge superstructure in Virginia // Journal of Performance of Constructed Facilities. 2005. Vol. 19. No. 2. Pp. 146-154.

29. Katkhuda H., Hanayneh B., Shatarat N. Influence of silica fume on high strength of lightweight concrete / World Academy of Science, Engineering and Technology. 2009. P. 5.

30. Yasar E., Atis C.D., Kilic A. High strength lightweight concrete made with ternary mixtures of cement, fly ash, silica fume, and scoria as aggregates // Turkish Journal of Engineering, Environment and Science. 2004. Vol. 28. Pp. 95-100.

31. Abdelhamid C., Jamal M.S., Saleh D. Ductility of reinforced lightweight concrete beams and columns // Latin American Journal of Solids and Structures. 2014. Vol. 11. No. 7. Pp. 1251-1274.

32. Бучкин А.В. Мелкозернистый бетон высокой коррозионной стойкости, армированный тонким базальтовым волокном: дис. ... канд. техн. наук. М., 2011. 130 с.

33. Ahmad S.H., Xie Y., Yu T. Shear ductility of reinforced lightweight concrete beams of normal strength and high strength concrete // Cement and Concrete Composites. 1995. Vol. 17. No. 2. Pp. 147-159.

34. Arisoy B., Wu H.C. Material characteristics of lightweight, high-performance concrete reinforced with PVA // Construction and Building Materials. 2008. Vol. 22. No. 4. Pp. 635-645.

35. Wang H.T., Wang L.C. Experimental study on static and dynamic mechanical properties of steel fiber reinforced lightweight aggregate concrete // Construction and Building Materials. 2013. Vol. 38. Pp. 1146-1151.

36. Balaguru P., Foden A. Properties of fiber reinforced structural lightweight concrete // American Concrete Institute Structural Journal. 1996. Vol. 93. Pp. 1-12.

37. ACI Committee 544. State-of-the-art report on fiber reinforced concrete // ACI 544.1R-96 (Reapproved 2002): manual of concrete practice. Michigan: American Concrete Institute, 2005. 